\title{
"Effect of financial leverage on firm growth: empirical evidence from listed firms in Amman stock exchange"
}

\begin{tabular}{|c|c|}
\hline AUTHORS & $\begin{array}{l}\text { Basem Hamouri (D https://orcid.org/0000-0001-5905-6904 } \\
\text { Mahmoud Al-Rdaydeh (D https://orcid.org/0000-0002-8810-4837 } \\
\text { R http://www.researcherid.com/rid/F-4993-2018 } \\
\text { Anas Ghazalat }\end{array}$ \\
\hline ARTICLE INFO & $\begin{array}{l}\text { Basem Hamouri, Mahmoud Al-Rdaydeh and Anas Ghazalat (2018). Effect of } \\
\text { financial leverage on firm growth: empirical evidence from listed firms in Amman } \\
\text { stock exchange. Investment Management and Financial Innovations, 15(2), 154- } \\
\text { 164. doi:10.21511/imfi.15(2).2018.14 }\end{array}$ \\
\hline DOI & http://dx.doi.org/10.21511/imfi.15(2).2018.14 \\
\hline RELEASED ON & Tuesday, 22 May 2018 \\
\hline RECEIVED ON & Tuesday, 13 March 2018 \\
\hline ACCEPTED ON & Friday, 04 May 2018 \\
\hline LICENSE & $\begin{array}{l}(c)) \text { EY-NC } \\
\text { This work is licensed under a Creative Commons Attribution-NonCommercial } 4.0 \\
\text { International License }\end{array}$ \\
\hline JOURNAL & "Investment Management and Financial Innovations" \\
\hline ISSN PRINT & $1810-4967$ \\
\hline ISSN ONLINE & $1812-9358$ \\
\hline PUBLISHER & LLC "Consulting Publishing Company "Business Perspectives" \\
\hline FOUNDER & LLC "Consulting Publishing Company "Business Perspectives" \\
\hline
\end{tabular}

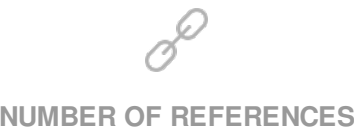

68

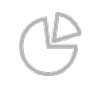

NUMBER OF FIGURES

0

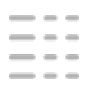

NUMBER OF TABLES

2

(c) The author(s) 2022. This publication is an open access article. 


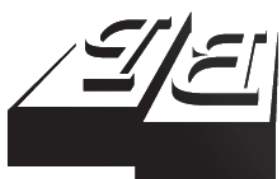

BUSINESS PERSPECTIVES

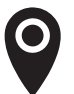

LLC "CPC "Business Perspectives" Hryhorii Skovoroda lane, 10, Sumy, 40022, Ukraine

www.businessperspectives.org

Received on: $13^{\text {th }}$ of March, 2018 Accepted on: $4^{\text {th }}$ of May, 2018

(C) Basem Hamouri, Mahmoud AlRdaydeh, Anas Ghazalat, 2018

Basem Hamouri, Associate Professor, Department of Finance, Business College, Al-Balqa Applied University in Sabbatical year at the Department of Finance, College of Business, Amman Arab University, Jordan.

Mahmoud Al-Rdaydeh, Assistant Professor, Department of Banking and Finance, Jadara University, Jordan.

Anas Ghazalat, Assistant Professor Department of Accounting, Jadara University, Jordan.

\section{(ㄷ)(1) (8)}

This is an Open Access article, distributed under the terms of the Creative Commons Attribution-NonCommercial 4.0 International license, which permits re-use, distribution, and reproduction, provided the materials aren't used for commercial purposes and the original work is properly cited.

\section{EFFECT OF FINANCIAL}

LEVERAGE ON FIRM GROWTH: EMPIRICAL EVIDENCE FROM LISTED FIRMS IN AMMAN STOCK EXCHANGE

\begin{abstract}
Past studies have mostly investigated the significance of financial attributes in trade affairs of developed countries, while dismissing such importance among developing nations. As such, this study looked into the influence of financial leverage upon the growth of Jordanian firms. For that purpose, a sample of 91 firms from Jordan had been analyzed via panel data regression method for the period between 2006 and 2015. As a result, the findings portrayed the irrelevance between financial leverage and growth of assets, but a significantly positive correlation with the growth of sales and employment. On top of that, this study revealed that growth of sales and employment had been significantly and positively correlated with firm size. In short, this study dismissed the speculation the constraint Jordanian firms were in, but on the contrary, displayed the ability to gain external financing to ascertain successful progress.
\end{abstract}

\section{Keywords \\ financial structure, leverage, firm growth, Jordan, listed firms}

\section{JEL Classification G32, L25, C23}

\section{INTRODUCTION}

Since the past three decades, Jordan has gone through substantial economic reformation in the attempt to gain financial liberty and integration at the global arena. Some of the effective aspects derived from the financial reformation had been privatization of firms owned by states, initiation of the trading sector, and trade preferences with foreign market that promotes investments from abroad and employment opportunities. On top of that, the initiative towards reforming its structure and legal aspects has opened more windows for business investments and opportunities in multiple arenas. Thus, the Amman Stock Exchange witnessed a spike in its mushrooming firms to some 236 firms in 2015, as compared to only 66 in 1978 . With that, the average growth rate for GDP escalated up to $7.1 \%$ in 2016 (CBJ, 2016). Hence, the financial reformation that took place in Jordan appeared to be a primary factor in its economic progress. Such progress leads to liberalization of the economics in the developing countries where companies are looking for future success. Nonetheless, such situations have a close relationship with financial decisions and investments of firms. So, firms usually diversify their capital to achieve the future goals that are directed towards growth factors and value creation in an attempt to survive and attract new investors and creditors. In fact, firms through issuing debt, use guarantees and/or warranties (provisions), issuing bonds and arranging lease financing, can revitalize the financial situation that may lead to growth in light of the diversification of the capital structure (Bodie, Kane, \& Marcus, 2013; Kieso, Weygandt, \& Warfield, 2010). 
Undoubtedly, a significant resource that ascertains the growth of a business is its financing. In particular, firms operating under favorable economic conditions are driven to use financial leverage to expand shareholder returns (Enekwe, Agu, \& Eziedo, 2014). However, firm's growth takes different aspects either in assets, profit, manpower or sale. The concept of growth is always associated with the concept of liquidity and the outsider financing since the firm value comprised of everlasting (Bei \& Wijewardana, 2012). Therefore, growth is controversial when determining firm's financial leverage.

Nevertheless, the association of firm growth with financing has yet to gain serious attention. In fact, contradicting results are depicted in the literature. For example, several researches discovered a negative correlation between firm growth and leverage (Aivazian, Ge, \& Qiu, 2005; Lang, Ofek, \& Stulz, 1996). On the other hand, growth of firm was positively linked to financial leverage in some studies (Anton, 2016; Hermelo \& Vassolo, 2007; Heshmati, 2001; Honjo \& Harada, 2006; Huynh \& Petrunia, 2010). In fact, varied measurements of firm growth (e.g., capital expenditures, net investment, as well as sales, assets, and employment growth) could possibly lead to such contradicting results, especially when linked with financial leverage (Anton, 2016). Hence, in an attempt to determine results reliability, this particular research investigated three firm growth measurements, as depicted in the literature, which were growth of sales, employment, and assets (Delmar, McKelvie, \& Wennberg, 2013; Guariglia, Liu, \& Song, 2011; Saeed, 2009; Sleuwaegen \& Goedhuys, 2002).

The focal problem of this study is to examine how the financial leverage affects the firms' growth factors in an emerging market such as Jordan within these conflict in the results of previous works. Only a handful of researchers have looked into Jordanian firm growth issues, especially in association of financial leverage. In fact, some studies have examined the correlation between firm size and firm growth (e.g. Al-Mahrouq, 2014; Almsafir, Nassar, Al-Mahrouq, \& Hayajneh, 2015), while most emphasized the impact of financial leverage upon performance and firm profitability (Al-Taani, 2013; Ramadan, 2015). With that, this research addressed several shortcomings detected in the literature by investigating the impact of financial leverage upon growth among Jordanian firms.

This study unfolds the following sections: section one depicts the literature review and the development of hypotheses, while section two presents both methodology and sample selection. Next, section three discusses the results retrieved, and lastly, the paper is concluded in final section.

\section{LITERATURE REVIEW}

The source for business growth has become a locus in the academic arena. The factors that determine the growth of a firm vary by firm size, economic health, as well as cultural and geographical variances, as depicted in the literature. Several studies have linked firm growth with firm size in certain industries (Davidsson \& Delmar, 2003; Gallagher \& Miller, 1991). Furthermore, researches pertaining to firm growth factors have been related to Gibrat's Law, which outlines the independent correlation between firm growth and firm size (e.g. Audretsch, Klomp, Santarelli, \& Thurik, 2004; Becchetti \& Trovato, 2002; Henrekson \& Johansson, 2010). On the contrary, some studies displayed rejection towards this law due to the inverse corre- lation found between the two variables (Delmar et al., 2013; García-Manjón \& Romero-Merino, 2012; Mudambi \& Swift, 2011).

Nonetheless, firm growth depends on several aspects, whereby financial resources is also an essential aspect, as depicted in numerous studies, both empirical and theoretical. In fact, some capital structure concepts have proven the significant impact of financial leverage upon firm growth. For example, the theory of pecking order developed by Myers and Majluf (1984) showed that internal sources for financing had been preferred compared to those external, as well as debt over external equity, so as to obtain symmetric data. Hence, internal financing could accelerate firm growth regardless of lower leverage. On the other hand, the capital structure theory also suggests 
the positive impact of financial leverage upon firm growth. Meanwhile, Jensen and Meckling (1976) displayed the role of debt in observing managers. Moreover, it has been stipulated that high levels of debts generate heightened result, which contradicts the findings derived from Myers (1977), where higher leverage leads to underinvestment as debtors benefit more with extra capital input when compared to equity holders, thus indicating a slow growth among firms. Meanwhile, Jensen (1986) claimed that with the case of overinvestment, a financially healthy firm may invest in risky projects, while those with debts would dismiss such notion. Therefore, a negative correlation is exhibited between firm growth investment and leverage, especially for firms with slim chances for growth.

In general, firm growth has not been positively related to leverage. For example, Stulz (1990) revealed cases of underinvestment due to limited cash flow especially when debts are settled using high leverage. Meanwhile, Dang (2011) discovered a case of underinvestment in UK due to leverage, whereby companies with high potential decrease leverage so as to avoid underinvestment by using cash to pay interests, hence restricting funds for further investments or the chance to grow. Besides, Sharpe (1994) examined the correlation between employment cyclicality and financial leverage, which pointed out the impacts of firm size and leverage upon workers amidst declining sales. He concluded that high-leveraged and small firms optimized workers at recession times, but failed to hire at economy rise.

Other than that, Anton (2016) revealed the positive effect of leverage upon firm growth, where firms with higher leverage displayed rapid growth that pointed out a correlation between firm growth and size, which is statistically significant. In short, smaller firms grow rapidly, whereas bigger firms progress slower. Next, Cantor (1990) proved the relationship between leverage and growth of employment rate, which indicated that higher leverage led to better employment rate and the fact that varied employment suggested better cash flow and spike in sales. However, such correlation disregards industry type, and firm growth or size. This is because firms with higher leverage would have problems in gaining more debts, thus would opt for retrenchment to secure profit.
Furthermore, Aivazian et al. (2005) investigated Canadian firms and discovered a negative relationship between leverage and investment, especially among firms with less growth probabilities. In fact, such finding is in agreement with Lang et al. (1996) who found a significantly negative effect between leverage and other variables linked to growth. Nevertheless, other researchers (e.g. Anton, 2016; Hermelo \& Vassolo, 2007; Heshmati, 2001; Honjo \& Harada, 2006; Huynh \& Petrunia, 2010) revealed a positive impact between growth of firm and leverage by using varied time spans and variables. Moreover, the positive influence exerted by leverage is associated with credit access and asymmetrical data.

The direction of correlation between firm growth and capital structure is uncertain as it is variable-dependent, whereby leverage, in particular, has exerted varied impacts upon varying firm growth variables. Thus, this study determined the viability of the results by evaluating growth via assets, sales, and employment so as to detect the precise impact of leverage upon firm growth variables. With that, this study examined selected firms in Jordan to identify the vital aspects for economy progress through the correlation of firm growth with financial leverage. Hence, the following hypotheses were developed:

H1: There is a positive effect of financial leverage on assets growth of firms in Jordan.

H2: There is a positive effect of financial leverage on employment growth of firms in Jordan.

H3: There is a positive effect of financial leverage on sales growth of firms in Jordan.

\section{RESEARCH METHODOLOGY}

\subsection{Research design}

As for this study, the method of panel data regression was employed in analyzing the data retrieved from year 2006 until 2015 so as to determine the impact of financial leverage upon growth among Jordanian firms. Hence, the sample was comprised of 91 firms with complete data obtained from the Amman Stock Exchange (ASE) for the stipulated 
period of time. Nevertheless, banking and financial institutions were excluded from the study due to their varied financial system (e.g. high level of regulation), as well as the noted exclusion in prior studies (e.g. Chui, Lloyd, \& Kwok, 2002; Omet \& Mashharawe, 2002; Schmukler \& Vesperoni, 2006).

\subsection{Measurement of variables}

As for this study, growth projected by Jordanian firms had been selected as the dependent variable. In fact, there are endless aspects to measure the growth of a firm, for instance, sales, manpower, share price, and total asset. As such, this study had applied three various determinants for firm growth based on literature, which were: i) total assets growth, ii) sales growth, as well as iii) employment growth (Delmar et al., 2013; Guariglia et al., 2011; Saeed, 2009; Sleuwaegen \& Goedhuys, 2002). Furthermore, as commonly performed, the log-differences for the three determinants were weighed in this study in order to investigate the growth of firm by using the equations given below:

$$
\log \left(A G_{i, t}\right)=\log \left(A_{i, t}\right)-\log \left(A_{i, t-1}\right),
$$

where $A G$ is asset growth, $A$ refers to total assets, $i$ denotes firm, and $t$ reflects year. Meanwhile, growth of assets in a firm is termed as the percentage of change recorded in value of assets at the time the study was conducted, while total asset value refers to the total worth of both tangible and intangible assets.

$$
\log \left(E G_{i, t}\right)=\log \left(E_{i, t}\right)-\log \left(E_{i, t-1}\right),
$$

where $E G$ is employment growth, $E$ denotes number of full-time employees, $i$ refers to firm, and $t$ reflects year. Other than that, growth of employment in firm is termed as percentage increment for those working full time at the time the study was conducted.

$$
\log \left(S G_{i, t}\right)=\log \left(S_{i, t}\right)-\log \left(S_{i, t-1}\right)
$$

where $S G$ is growth of sales, $S$ refers to total sales, $i$ denotes firm, and $t$ reflects year. Besides, growth of sales in firm is termed as the percentage in change for sales at the time the study was conducted. Meanwhile, growth of sales appears to be a commonly applied determinant in order to meas- ure growth of firm due to its reflection upon shifts that take place for both long and short periods, as well as the firm capacity for sales of goods and services, thus reckoning the firm and its related activities (Coad \& Hölzl, 2012; Delmar et al., 2013).

On the other hand, financial leverage was chosen as the independent variable. In fact, this variable was determined by setting the total liabilities: total assets ratio in several researches concerning capital structure (e.g. Anton, 2016; Avarmaa, 2011; Huizinga, Laeven, \& Nicodeme, 2008; Rajan \& Zingales, 1995). Such approach presents two primary benefits, which are: i) trade credit is reckoned as a short period source for financing, and ii) made avail for most firms. Thus, the following equation reflects the calculation for financial leverage:

$$
L E V_{(i, t)}=\frac{T L_{(i, t)}}{T A_{(i, t)}},
$$

where $L E V$ refers to financial leverage, $T L$ denotes total liabilities of a firm, $T A$ is total assets of a firm, $i$ reflects firm, and $t$ is year. The equation determines the degree of financial leverage of a firm in order to cater to the related trade activities.

A total of five control variables had been employed in this study. As a significant pointer for financing patterns of a firm, firm size had been selected as a control variable (Beck, Demirguc-Kunt, Laeven, \& Levine, 2008). This is because a firm that is small in size suggests less external and informal financing, when compared to conglomerates in viewpoint of facilities for credit. Nonetheless, past researches have yet to establish the correlation between firm growth and firm size (Evans, 1987; Storey, 1994; Wiklund, 1998). In fact, several studies indicated the possibility of small firms to experience financial constriction, thus a negative impact upon financial growth (Audretsch \& Elston, 2002; Oliveira \& Fortunato, 2006). With that, a positive correlation is projected between firm growth and size (Katsikeas \& Piercy, 1993; Wiklund, 1998). On the contrary, some papers depicted the rapid growth among smaller firms, when compared to huge firms (Almeida \& Campello, 2007; Katsikeas \& Piercy, 1993). Hence, firm size had been selected as a control variable. Besides, algorithms related 
to total assets were adopted as the measuring tool for this particular variable mainly to overcome issues of outliers in regression analysis.

The age was selected as the second control variable due to its significance among more recently established firms regarding their dependence upon internal financing, as well as their rapid progress, in comparison to older firms. Nevertheless, the literature depicts varied opinions concerning the correlation of firm growth with age. For example, several researches asserted the positive impact between firm age and growth (e.g. Das, 1995; Elston, 1993), while negative association in some others for the said variables (Becchetti \& Trovato, 2002; Hobdari, Jones, \& Mygind, 2009). Such variances could emerge due to intricacy and multi-dimensionality of the growth aspect projected by small firms. Furthermore, based on the hypothesis that is based on resources, financial resources get enhanced as firms mature. As such, a positive correlation could be established between firm growth and age. However, Yasuda (2005) revealed a significant relationship between firm size and age, thus a negative impact of age upon growth. As for this study, the age of firms was determined at the end of year 2015 and logarithms linked to firm age were employed to overcome outliers in regression analysis.

Next, industry sector was chosen as the third control variable, as depicted to be a pointer for growth of firms (Delmar, Davidsson, \& Gartner, 2003; Wiklund, Davidsson, Delmar, \& Aronsson, 1997). With relationship among firms within certain industry, a pulling effect may be established for the firms related within the sector (Gilbert, McDougall, \& Audretsch, 2006). Other variables with significant impacts upon firm growth are the progress phase of an industry (Gilbert et al., 2006), and the network position among firms. With that, in order to control the impacts of certain industries, this study adhered to Beck, Demirgüç-Kunt, and Maksimovic (2005) suggestion, which categorized the firms into two sectors: i) services sector, and ii) industrial sector. Hence, two dummy variables were conjured in this study: 'Dummy industrial' and 'Dummy services'.

Moving on, profitability of firm was chosen as the fourth control variable due to its importance as a firm growth pointer (e.g. Demirgüç-Kunt \& Maksimovic, 1998; Gulati \& Zantout, 1997). Thus, ROA was applied as a locus to determine firm profitability. Lastly, level of liquidity was selected as the final control variable, if firms hold a sustained level of short-term liquidity, then they will be able to pay their short-term liabilities, which could lead to faster growth. This variable was measured by the current ratio (current assets divided on current liabilities) as in Mateev and Anastasov (2010).

\subsection{Data analysis techniques and empirical models}

The time series cross-sectional method (analysis of panel data) was performed in this study in order to examine the correlations between the chosen variables. In fact, the analysis of panel data has been commonly employed worldwide for its dependence upon data gathered from observations made at varied points of time (Hsiao, 1986; Yaffee, 2003). Furthermore, the panel data analysis is beneficial for its capability in discarding unobserved heterogeneity at each observation point, reduced multicollinearity in the variables, additional freedom degrees, and decreased biasness (Baltagi, 2005).

The models depicted as follows are comprised of mathematical elaborations that had been considered in this study so as to attain the outlined objectives, in which the approach of multiple regression had been performed using the following formulae:

$$
\begin{aligned}
& A G_{i t}=a+\beta_{1} L E V_{i t}+\beta_{2} S I Z E_{i t}+\beta_{3} A G E_{i t}+ \\
& +\beta_{4} T I_{i t}+\beta_{5} R O A_{i t}+\beta_{6} C R_{i t}+\varepsilon_{i t}, \\
& E G_{i t}=a+\beta_{1} L E V_{i t}+\beta_{2} S I Z E_{i t}+\beta_{3} A G E_{i t}+ \\
& +\beta_{4} T I_{i t}+\beta_{5} R O A_{i t}+\beta_{6} C R_{i t}+\varepsilon_{i t}, \\
& S G_{i t}=a+\beta_{1} L E V_{i t}+\beta_{2} S I Z E_{i t}+\beta_{3} A G E_{i t}+ \\
& +\beta_{4} T I_{i t}+\beta_{5} R O A_{i t}+\beta_{6} C R_{i t}+\varepsilon_{i t},
\end{aligned}
$$

where $A G$ represents asset growth, $E G$ represents employment growth, $S G$ represents sales growth, $L E V$ refers to financial leverage, SIZE refers to firm size, $A G E$ refers to the age of firm, $T I$ represents the type of industry, $R O A$ refers to the return on assets, $C R$ refers to the current ratio. 


\section{EMPIRICAL RESULTS}

\subsection{Descriptive statistics}

The variable 'type of industry' had been embedded for analysis to group the sample based on categories of listed firms in ASE. Besides, the variable exhibited that industrial firms comprised of 54.9\% from 500 observations. Meanwhile, the remaining 410 firms or $45.1 \%$ of the sample had been related to services.

Table 1 shows the descriptive statistics that reflects continuous variables in mean, minimum, maximum, and standard deviation values. Initially, firm growth (dependent variable) was evaluated by using three determinants: sales growth $(S G)$, assets growth $(A G)$, and employment growth $(E G)$. Furthermore, the table shows that $A G$ recorded $7.4 \%$ at an average and varied between $-54 \%$ and $365 \%$. Meanwhile, $E G$ had a lower average when compared to $A G$ at $6.7 \%$ and $373 \%$ as its minimum and maximum values, respectively. Lastly, $S G$ displayed the highest average at $12.7 \%$ and varied between $-2.24 \%$ and $366 \%$. Thus, the findings reflect some high values at certain time points, while low for the rest, which is common for growth-related issues. Besides, some firms attain growth from diversifying their product types by adhering to a strategy called merger or acquisition that is by far cheaper, but effective for growth of firms (Hitt, Harrison, \& Ireland, 2001; Papadakis, 2007). In fact, firms that employ such strategy could potentially increase the related growth pointers, for instance, $A G, E G$, and $S G$, which were investigated in this study. However, these firms may face hurdles, which could lead to giving up some parts of the companies. Hence, decisions made at the spur of moment could negatively affect $A G, S G$ and $E G$. In addition, the table also shows the descriptive statistics for explanatory variables. In evaluating the impact of financial leverage ( $L E V)$ upon firm growth, ratio of total liabilities to total assets had been calculated. As a result, the mean ratio for $L E V$ was approximately $51 \%$, which varied between $0.7 \%$ and $253 \%$, indicating firm dependence upon $L E V$ at $253 \%$ of total assets. In precise, the firms highly depend upon external financing as the main financing source, which is in line with the findings retrieved from Ayyagari, DemirgüçKunt, and Maksimovic (2012) who discovered the high dependence among developing nations upon external finance for its businesses.

As for the control variables, the first variable, which is firm size (SIZE), was evaluated using total assets logarithm, which varied between 13.5 and 21.3 with 17.1 mean ratio. Meanwhile, firm age (AGE) was examined using natural logarithm and resulted in variation from 0.13 to 4.35 with 2.49 mean ratio. $R O A$ was the third control variable, displayed an average at $2.19 \%$ and varied from $-60 \%$ to $49.5 \%$. Lastly, the liquidity level, was examined using the current ratio $(C R)$, showed an average of 2.23 times with maximum 28 times. This indicates that Jordanian firms are able to generate a good level of liquidity, which could spur their growth.

\subsection{Regression analysis}

This study employed the regression model in accordance to the findings obtained from the Hausman test. Besides, in order to determine the robustness of the results, several diagnostics tests were performed, such as autocorrelation, multicollinearity, heteroscedasticity, and panel unit root tests. The said tests ensured the reliability of regression models and addressed issues related to econometric. As a result, the data were ascertained to have no multicollinearity or stationary

Table 1. Descriptive statistics

\begin{tabular}{|c|c|c|c|c|c|}
\hline Variables & Observations & Mean & Std. Dev. & Minimum & Maximum \\
\hline AG & 910 & 0.0749 & 0.2318 & -0.5413 & 3.6521 \\
\hline EG & 910 & 0.0673 & 0.2592 & -2.3989 & 3.7376 \\
\hline SG & 910 & 0.1268 & 0.4112 & -2.2430 & 3.6645 \\
\hline LEV & 910 & 0.5163 & 0.3264 & 0.0076 & 2.5300 \\
\hline SIZE & 910 & 17.114 & 1.3380 & 13.495 & 21.310 \\
\hline AGE & 910 & 2.4972 & 1.2314 & 0.0013 & 4.3567 \\
\hline $\mathrm{ROA}$ & 910 & 0.0219 & 0.0982 & -0.6001 & 0.4946 \\
\hline $\mathrm{CR}$ & 819 & 2.2344 & 2.7445 & 0.0005 & 28.0901 \\
\hline
\end{tabular}


issues, but some problems related to heteroscedasticity and autocorrelation were present. Therefore, in the attempt to overcome the mentioned issue, the fixed effects cluster standard errors approach was performed.

Following that, Table 2 shows the results obtained from the regression of amended model, which examined $H 1, H 2$, and $H 3$ in their relation to the effect of $L E V$ upon $A G, E G$, and $S G$, as the selected firm growth determinants. Additionally, the model displayed accepted goodness of fit for significant $F$-statistic, in which $14 \%$ of variations could be explained by dependent variables in model (2), whereas $20 \%$ and $19 \%$ of variations by independent variables in models (1) and (3), respectively. Furthermore, the findings of $R$ squared are in line with those of prior studies, which asserted that firm growth is determined by several factors, in which financing is one of them. Nonetheless, results of regression for model (1) signified nil correlation between $L E V$ and $A G$ among Jordanian companies, whereas models (2) and (3) exhibited significantly positive correlations between $L E V$ and $E G$, as well as $L E V$ and $S G$, at $10 \%$ and $1 \%$, respectively. Hence, increment of labor force or otherwise is closely associated to financial leverage. All in all, the aspect of finance has been proven to have somewhat effect upon firm growth, which also confirms the conclusions made in past studies for business operations among both developed and developing nations (Anton, 2016; Hermelo \& Vassolo, 2007; Heshmati, 2001; Honjo \& Harada, 2006; Huynh \& Petrunia, 2010). Such results imply that the ability to obtain debt financing is vital for the growth of Jordanian firms. Due to underdeveloped capital market among developing nations, businesses can boost if debt financing is granted.
In fact, this vey issue is halting progress in trade among developing nations (Ayyagari et al., 2012). Moreover, the information asymmetry makes the firms more dependent on external fund rather than the equity capital. Based on these findings, it can be concluded that Jordanian firms should rely more on using financial leverage to finance their operations and increase the income, and make greater returns. This conclusion confirms theoretical literature believing that financing debts is cheaper than equity and that debts generate tax shield, so this factor can be desired by firms to get more liabilities.

On top of that, Table 2 also displays the results obtained from regression for the control variables in all the tested models. Interestingly, firm size had no relationship with assets growth in model (1), but appeared to have significantly positive correlations with sales and employment growth in models (2) and (3). This pointed out that most of the firms that had been examined were large in size and did not experience any financial issue. Such conclusion is made, because several studies signified the possibility of small firms to face financial constriction, thus negatively affecting financial growth (Audretsch \& Elston, 2002; Oliveira \& Fortunato, 2006).

Next, firm age appeared to display a significantly negative correlation with other growth determinants, which is opposed to the hypothesis based on resource that held the notion improvement of financial resources as a firm matures. Hence, firm age could be positively related to firm growth. However, the findings for firm age in all the tested models are in agreement with those revealed by Yasuda (2005), which asserted that strong corre-

Table 2. Regression analysis

\begin{tabular}{|c|c|c|c|c|c|c|}
\hline \multirow{2}{*}{$\begin{array}{c}\text { Dep/Indep. } \\
\text { variables }\end{array}$} & \multicolumn{2}{|c|}{$\begin{array}{c}\text { Model (1) } \\
\text { AG }\end{array}$} & \multicolumn{2}{|c|}{$\mathrm{EG}_{\mathrm{EG}}^{\text {Model (2) }}$} & \multicolumn{2}{|c|}{$\begin{array}{c}\text { Model (3) } \\
\text { SG }\end{array}$} \\
\hline & Coefficient & t-statistic & Coefficient & t-statistic & Coefficient & t-statistic \\
\hline LEV & 0.1061 & 1.03 & 0.0801 & $1.20 *$ & 0.3836 & $2.77^{* * *}$ \\
\hline SIZE & 0.1054 & $1.83^{*}$ & 0.0926 & $3.59 * * *$ & 0.1214 & 1.25 \\
\hline AGE & -0.3099 & $-2.99 * * *$ & -0.2124 & $-2.06^{* *}$ & -0.3994 & $-4.44 * * *$ \\
\hline ROA & 0.4601 & $2.96^{* * *}$ & 0.2708 & $1.93 *$ & 1.0984 & $4.17^{* * *}$ \\
\hline CR & 0.0067 & 0.74 & -0.0083 & $-1.73^{*}$ & 0.0104 & 0.90 \\
\hline $\mathrm{R} 2$ & \multicolumn{2}{|c|}{0.20} & \multicolumn{2}{|c|}{0.14} & \multicolumn{2}{|c|}{0.19} \\
\hline F-statistic & \multicolumn{2}{|c|}{0.00} & \multicolumn{2}{|c|}{0.00} & \multicolumn{2}{|c|}{0.00} \\
\hline
\end{tabular}

Note: Significant level ${ }^{\star * \star} 1 \%,{ }^{* *} 5 \%$ and ${ }^{\star} 10 \%$. 
lation between firm size and age, hence the negative impact of age upon firm growth. Other than that, the three models were tested using the fixed effect regression approach. Consequently, type of industry (TI), which is the third control variable, was excluded from further analysis due to issues related to multicollinearity. For the firm profitability $(R O A)$, which is the fourth control variable, displayed a strong correlation with firm growth, which happens to be in agreement with some prior studies that asserted its essential role as a pointer for firms' growth (Demirgüç-Kunt \& Maksimovic, 1998; Gulati \& Zantout, 1997). Lastly, as for the final control variable $C R$, the results showed that this variable has a weak significant positive relationship with employment growth and no correlation with sales and assets growth. Such results are consistent with the assertion that firms in developing countries are highly dependent on external funds.

\section{CONCLUSION}

This study had primarily investigated the impact of financial leverage upon growth of Jordanian firms. Disparate from its neighboring nations, such as Iraq, Syria, and Palestine, Jordan has been claimed to be a nation with stability in all aspects. Besides, the reformation of economy that took place thirty years ago has positioned its firms as a significant aspect for economy progress. Hence, such details and the positive correlation revealed in prior studies between firm growth and leverage functioned as motivation to further investigate financial leverage linked with some selected firm growth determinants. In fact, this study revealed that healthy financial leverage promotes progress in firms, which is in line with studies carried out by Heshmati (2001), Hermelo and Vassolo (2007), Honjo and Harada (2006), Huynh and Petrunia (2010), as well as Anton (2016).

Next, in the attempt to examine the reliability of the results, firm growth was further evaluated using three pointers: assets growth, employment growth, and sales growth. As a result, it was found that assets growth was insignificant to finance, mainly because most firms located in Jordan used debts that are short-term to enhance their short-term activities, but not those with long-term ones. Thus, the hypothesis is not supported. Meanwhile, as for employment and sales growth pointers, significantly positive correlations were established with leverage, hence signifying that the hypothesis is indeed supported. This could be due to the fact that their finance is well managed in these firms. Besides, at the time of data analyses, an interesting observation was noted, whereby the most common types of firms debts had been short-term loans and overdrafts so as to effectively manage their debts, besides enhancing their financial position that reflects their reputation in the trade arena. As such, loan renewal or applications can be carried out without hurdles and well-performing firms are reflective of their progress. Other than that, the findings also project that the Jordanian firms could address their financial constriction smoothly, thus enabling financial boost, which is in line with the findings retrieved from a study conducted by Volk and Trefalt (2014) who highlighted the fact that financing supports firm growth to address finance-related issues by gaining easy access to external financing and less dependency upon internal financing, which all together heighten the financial progress rate of a firm.

Moreover, most of the studies related to this subject matter had been carried out in developed nations. Thus, it is essential to determine the correlation between the selected variables in the emerging market of Jordan, which varies from several attributes, for instance, political system, corporate capital structure, corporate governance, ownership structure, taxation system, liquidation law, as well as fresh financial systems in this competitive world. With that, the results obtained from this study could enhance one's comprehension regarding the impact of leverage upon firm growth among developing nations, Jordan alike.

Furthermore, this study contributes significantly to both business sectors, banking sector and policymakers in Jordan. This is because the findings retrieved from this study could function as inputs for 
further effective policy planning to suit the business culture practiced in Jordan, as well as it could encourage bank's manager to put a long plan to provide more credit to the economic sectors. For instance, the positive correlations of leverage with firm growth may encourage banks' stakeholders and managers to offer more credit for firms with affordable interest rate, which ultimately leads to increase the profit of banking sector. Also, the results of the current study could be a guidance to the relevant authorities in Jordan such as the Central Bank of Jordan, ASE, or other regulatory bodies, where benefits can be reaped from this study results. Most importantly, the related authorities could assess the present scenario of the banking sector in Jordan, and use the inputs towards the progress of trading line and economic boost in Jordan.

\section{REFERENCES}

1. Aivazian, V. A., Ge, Y., \& Qiu, J. (2005). The impact of leverage on firm investment: Canadian evidence. Journal of corporate finance, 11(1), 277-291. https://doi.org/10.1016/ S0929-1199(03)00062-2

2. Al-Mahrouq, M. H. (2014). The Relationship Between Firm Size and Growth in the Manufacturing Sector in Jordan. Dirasat: Administrative Sciences, 33(1). Retrieved from https://journals. ju.edu.jo/DirasatAdm/article/ view/10

3. Al-Taani, K. (2013). The relationship between capital structure and firm performance: evidence from Jordan. Journal of Finance and Accounting, 1(3), 41-45. https://doi. org/10.11648/j.jfa.20130103.11

4. Almeida, H., \& Campello, $M$. (2007). Financial constraints, asset tangibility, and corporate investment. Review of Financial Studies, 20(5), 1429-1460. https:// doi.org/10.1093/rfs/hhm019

5. Almsafir, M. K., Nassar, I. A., AlMahrouq, M. H., \& Hayajneh, J. A. (2015). The Validity of Gibrat's Law: Evidence from the Service Sector in Jordan. Procedia Economics and Finance, 23, 1602-1606. https://doi. org/10.1016/S2212-5671(15)004189

6. Anton, S. G. (2016). The Impact of Leverage on Firm Growth. Empirical Evidence from Romanian Listed Firms. Review of Economic and Business Studies, 9(2), 147-158. https://doi.org/10.1515/rebs-20160039

7. Audretsch, D. B., \& Elston, J. A. (2002). Does firm size matter? Evidence on the impact of liquidity constraints on firm investment behavior in Germany. International Journal of Industrial Organization, 20(1), 1-17. https://doi.org/10.1016/S01677187(00)00072-2

8. Audretsch, D. B., Klomp, L., Santarelli, E., \& Thurik, A. R. (2004). Gibrat's law: are the services different? Review of Industrial Organization, 24(3), 301-324. https://doi.org/10.1023/ B:REIO.0000038273.50622.ec

9. Avarmaa, M. (2011). Does leverage affect company growth in the Baltic countries. Paper presented at the 2011 International Conference on Information and Finance (IPEDR).

10. Ayyagari, M., Demirgüç-Kunt, A., \& Maksimovic, V. (2012). Financing of Firms in Developing Countries: Lessons from Research (World Bank Policy Research Working Paper 6036). Retrieved from https://ssrn.com/abstract $=2039204$

11. Baltagi, B. (2005). Econometric analysis of panel data. John Wiley $\&$ Sons.

12. Becchetti, L., \& Trovato, G. (2002). The determinants of growth for small and medium sized firms. The role of the availability of external finance. Small Business Economics, 19(4), 291-306. https://doi. org/10.1023/A:1019678429111

13. Beck, T., Demirguc-Kunt, A., Laeven, L., \& Levine, R. (2008). Finance, firm size, and growth. Journal of money, credit and banking, 40(7), 1379-1405. https://doi.org/10.1111/j.15384616.2008.00164.x
14. Beck, T., Demirgüç-Kunt, A., \& Maksimovic, V. (2005). Financial and legal constraints to growth: Does firm size matter? The Journal of Finance, 60(1), 137-177. https://doi.org/10.1111/j.15406261.2005.00727.x

15. Bei, Z., \& Wijewardana, W. (2012). Financial leverage, firm growth and financial strength in the listed companies in Sri Lanka. ProcediaSocial and Behavioral Sciences, 40, 709-715. https://doi.org/10.1016/j. sbspro.2012.03.253

16. Bodie, Z., Kane, A., \& Marcus, A. J. (2013). Essentials of investments. McGraw-Hill/Irwin.

17. Cantor, R. (1990). Effects of Leverage on Corporate Investment and Hiring Decisions. Federal Reserve Bank of New York Quarterly Review (Summer), 31-41. Retrieved from https://www.newyorkfed.org/medialibrary/media/research/quarterly_review/1990v15/ v15n2article3.pdf

18. CBJ (2016). Annual Report of Central Bank of Jordan. Retrieved from http://www.cbj.gov.jo/Pages/ viewpage.aspx?pageID $=337$

19. Chui, A. C., Lloyd, A. E., \& Kwok, C. C. (2002). The determination of capital structure: is national culture a missing piece to the puzzle? Journal of international business studies, 33(1), 99-127. https://doi.org/10.1057/palgrave. jibs. 8491007

20. Coad, A., \& Hölzl, W. (2012). Firm Growth: Empirical Analysis. In Handbook on the Economics and Theory of the Firm. Cheltenham, UK: Edward Elgar Publishing. 
21. Dang, V. A. (2011). Leverage, debt maturity and firm investment: An empirical analysis. Journal of Business Finance \& Accounting, 38(1-2), 225-258. https://doi.org/10.1111/j.14685957.2010.02215.x

22. Das, S. (1995). Size, age and firm growth in an infant industry: The computer hardware industry in India. International Journal of Industrial Organization, 13(1), 111126. https://doi.org/10.1016/01677187(94)00453-9

23. Davidsson, P., \& Delmar, F. (2003). Hunting for new employment: the role of high-growth firms. In Small firms and economic development in developed and transition economies: A reader (pp. 7-20).

24. Delmar, F., Davidsson, P., \& Gartner, W. B. (2003). Arriving at the high-growth firm. Journal of Business Venturing, 18(2), 189-216. https://doi.org/10.1016/S08839026(02)00080-0

25. Delmar, F., McKelvie, A., \& Wennberg, K. (2013). Untangling the relationships among growth, profitability and survival in new firms. Technovation, 33(8-9), 276-291. https://doi.org/10.1016/j. technovation.2013.02.003

26. Demirgüç-Kunt, A., \& Maksimovic, V. (1998). Law, finance, and firm growth. The Journal of Finance, 53(6), 2107-2137. https://doi. org/10.1111/0022-1082.00084

27. Elston, J. A. (1993). Firm ownership structure and investment: Theory and evidence from German panel data. WZB, Forschungsschwerpunkt Marktprozess und Unternehmensentwicklung.

28. Enekwe, C. I., Agu, C. I., \& Eziedo, K. (2014). The effect of financial leverage on financial performance: evidence of quoted pharmaceutical companies in Nigeria. IOSR Journal of Economics and Finance (IOSR$J E F), 5(3), 17-25$. Retrieved from https://pdfs.semanticscholar. org/d2a4/bea1a204cdabbfb4cf39b95012a7ea7832cc.pdf
29. Evans, D. S. (1987). The relationship between firm growth, size, and age: Estimates for 100 manufacturing industries. The journal of industrial economics, 567-581. Retrieved from http:// www.jstor.org/stable/2098588

30. Gallagher, C., \& Miller, P. (1991). New fast-growing companies create jobs. Long Range Planning 24(1), 96-101. https://doi. org/10.1016/0024-6301(91)90029-N

31. García-Manjón, J. V., \& RomeroMerino, M. E. (2012). Research, development, and firm growth. Empirical evidence from European top R\&amp;D spending firms. Research Policy, 41(6), 10841092. https://doi.org/10.1016/j. respol.2012.03.017

32. Gilbert, B. A., McDougall, P. P., \& Audretsch, D. B. (2006). New venture growth: A review and extension. Journal of management, 32(6), 926-950. https://doi. org/10.1177/0149206306293860

33. Guariglia, A., Liu, X., \& Song, L. (2011). Internal finance and growth: microeconometric evidence on Chinese firms. Journal of Development Economics, 96(1), 79-94. https://doi. org/10.1016/j.jdeveco.2010.07.003

34. Gulati, D., \& Zantout, Z. (1997). Inflation, capital structure, and immunization of the firm's growth potential. Journal Of Financial And Strategic Decisions, 10(1), 77-90. Retrieved from http://www. studyfinance.com/jfsd/pdffiles/ v10n1/gulati.pdf

35. Henrekson, M., \& Johansson, D. (2010). Gazelles as job creators: a survey and interpretation of the evidence. Small Business Economics, 35(2), 227-244. https:// doi.org/10.1007/s11187-0099172-z

36. Hermelo, F. D., \& Vassolo, R. (2007). The Determinants of Firm's Growth: An Empirical Examination. Revista Abante, 10(1), 3-20. Retrieved from http:// eacc10.puc.cl/files/ABT/Contenidos/Vol-10-N1/Diaz.pdf

37. Heshmati, A. (2001). On the growth of micro and small firms: evidence from Sweden.
Small business economics, 17(3), 213-228. https://doi. org/10.1023/A:1011886128912

38. Hitt, M. A., Harrison, J. S., \& Ireland, R. D. (2001). Mergers and acquisitions. A guide to creating value for stakeholders. Oxford University Press.

39. Hobdari, B., Jones, D. C., \& Mygind, N. (2009). Capital investment and determinants of financial constraints in Estonia. Economic Systems, 33(4), 344-359. https://doi.org/10.1016/j.ecosys.2009.05.004

40. Honjo, Y., \& Harada, N. (2006). SME policy, financial structure and firm growth: evidence from Japan. Small Business Economics, 27(4), 289-300. https://doi. org/10.1007/s11187-005-6703-0

41. Hsiao, C. (1986). Analysis of Panel Data (1st ed.). Cambridge, UK: Cambridge University Press.

42. Huizinga, H., Laeven, L., \& Nicodeme, G. (2008). Capital structure and international debt shifting. Journal of financial economics, 88(1), 80-118. https://doi.org/10.1016/j.jfineco.2007.05.006

43. Huynh, K. P., \& Petrunia, R. J. (2010). Age effects, leverage and firm growth. Journal of Economic Dynamics and Control, 34(5), 1003-1013. https://doi. org/10.1016/j.jedc.2010.01.007

44. Jensen, M. C. (1986). Agency costs of free cash flow, corporate finance, and takeovers. The American Economic Review, 76(2), 323-329. Retrieved from http://www.jstor. org/stable/1818789

45. Jensen, M. C., \& Meckling, W. H. (1976). Theory of the firm: Managerial behavior, agency costs and ownership structure. Journal of financial economics, 3(4), 305360. https://doi.org/10.1016/0304405X(76)90026-X

46. Katsikeas, C. S., \& Piercy, N. F. (1993). Long-term export stimuli and firm characteristics in a European LDC. Journal of International Marketing, 23-47. Retrieved from http://www.jstor. org/stable/25048505 
47. Kieso, D. E., Weygandt, J. J., \& Warfield, T. D. (2010) Intermediate accounting: IFRS edition (Vol. 2). John Wiley \& Sons.

48. Lang, L., Ofek, E., \& Stulz, R. (1996). Leverage, investment, and firm growth. Journal of financial economics, 40(1), 3-29. https://doi.org/10.1016/0304405X(95)00842-3

49. Mateev, M., \& Anastasov, Y. (2010). Determinants of small and medium sized fast growing enterprises in Central and Eastern Europe: a panel data analysis. Financial Theory and Practice, 34(3), 269-295. Retrieved from https://hrcak.srce.hr/63156

50. Mudambi, R., \& Swift, T. (2011). Proactive R\&amp;D management and firm growth: A punctuated equilibrium model. Research Policy, 40(3), 429-440. https://doi. org/10.1016/j.respol.2010.10.014

51. Myers, S. C. (1977). Determinants of corporate borrowing. Journal of financial economics, 5(2), 147-175. https://doi.org/10.1016/0304405X(77)90015-0

52. Myers, S. C., \& Majluf, N. S. (1984). Corporate financing and investment decisions when firms have information that investors do not have. Journal of financial economics, 13(2), 187-221. https://doi.org/10.1016/0304405X(84)90023-0

53. Oliveira, B., \& Fortunato, A. (2006). Firm growth and liquidity constraints: A dynamic analysis. Small Business Economics, 27(2-3), 139-156. https://doi.org/10.1007/ s11187-006-0006-y

54. Omet, G., \& Mashharawe, F. (2002). The capital structure choice in tax contrasting environments: evidence from the Jordanian, Kuwaiti, Omani and Saudi corporate sectors. Paper presented at the The Economic

Research Form $10^{*}$ Annual

Conference. Retrieved from http://

citeseerx.ist.psu.edu/viewdoc/dow

nload?doi $=10.1 \cdot 1 \cdot 621.9841 \& \mathrm{rep}=\mathrm{r}$ ep1\&type $=$ pdf

55. Papadakis, V. (2007). Growth through mergers and acquisitions: how it won't be a loser's game. Business Strategy Series, 8(1), 43-50. https://doi. org $/ 10.1108 / 17515630710686879$

56. Rajan, R. G., \& Zingales, L. (1995). What do we know about capital structure? Some evidence from international data. the Journal of Finance, 50(5), 1421-1460. https:// doi.org/10.1111/j.1540-6261.1995. tb05184.x

57. Ramadan, I. Z. (2015). Leverage and the Jordanian firms' value: empirical evidence. International Journal of Economics and Finance, 7(4), 75. http://dx.doi.org/10.5539/ ijef.v7n4p75

58. Saeed, A. (2009). Does nature of financial institutions matter to firm growth in transition economies. Eurasian Journal of Business and Economics, 2(3), 73-90. Retrieved from http://www. ejbe.org/EJBE2009Vol02No03p73SAEED.pdf

59. Schmukler, S. L., \& Vesperoni, E. (2006). Financial globalization and debt maturity in emerging economies. Journal of Development Economics, 79(1), 183-207. https://doi.org/10.1016/j.jdeveco.2004.12.006

60. Sharpe, S. A. (1994). Financial market imperfections, firm leverage, and the cyclicality of employment. The American Economic Review, 84(4), 10601074. Retrieved from http://www. jstor.org/stable/2118044

61. Sleuwaegen, L., \& Goedhuys, M. (2002). Growth of firms in developing countries, evidence from Cote d'Ivoire. Journal of Development Economics, 68(1), 117-135. https://doi.org/10.1016/ S0304-3878(02)00008-1

62. Storey, D. J. (1994). Understanding the small business sector. University of Illinois at Urbana-Champaign's Academy for Entrepreneurial Leadership Historical Research Reference in Entrepreneurship.

63. Stulz, R. (1990). Managerial discretion and optimal financing policies. Journal of financial economics, 26(1), 3-27. https://doi. org/10.1016/0304-405X(90)90011-N

64. Volk, M., \& Trefalt, P. (2014). Access to Credit as a Growth Constraint. Journal of Banking and Financial Economics, 1(1), 29-39. Retrieved from http://www.wz.uw. edu.pl/portaleFiles/3842-journalof-b/articles/04JBFE112014VolkT refalt.pdf

65. Wiklund, J. (1998). Small firm growth and performance: Entrepreneurship and beyond. Internationella Handelshögskolan.

66. Wiklund, J., Davidsson, P., Delmar, F., \& Aronsson, M. (1997). Expected consequences of growth and their effect on growth willingness in different samples of small firms. Frontiers of entrepreneurship research, 1-16. Retrieved from https://fusionmx. babson.edu/entrep/fer/papers97/ wiklund/wik1.htm

67. Yaffee, R. (2003). A primer for panel data analysis. Connect Information Technology at NYU, 1-11. Retrieved from http://citeseerx.ist.psu.edu/viewdoc/downloa $\mathrm{d}$ ?doi=10.1.1.595.1905\&rep=rep1 \&type $=$ pdf

68. Yasuda, T. (2005). Firm growth, size, age and behavior in Japanese manufacturing. Small Business Economics, 24(1), 1-15. https://doi. org/10.1007/s11187-005-7568-y 